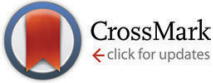

Cite this: New J. Chem., 2016, 40,4818

Received (in Montpellier, France)

3rd December 2015,

Accepted 14th March 2016

DOI: $10.1039 / c 5 n j 03360 h$

www.rsc.org/njc

\section{Platinum(II) complexes with hybrid amine- imidazolin-2-imine ligands and their reactivity toward bio-molecules $\dagger$}

\author{
Jovana Bogojeski, ${ }^{a}{ }^{a}$ Jeroen Volbeda, ${ }^{b}$ Živadin D. Bugarčić, ${ }^{a}$ Matthias Freytag ${ }^{\mathrm{b}}$ and \\ Matthias Tamm ${ }^{\mathrm{b}}$
}

\begin{abstract}
Two new Pt(II) complexes with imidazolin-2-imines as ancillary ligands, $\left[\mathrm{Pt}\left(\mathrm{DMEAlm}{ }^{\mathrm{iPr}}\right) \mathrm{Cl}_{2}\right]$ and $\left[\mathrm{Pt}\left(\mathrm{DPENIm}{ }^{\mathrm{iPr}}\right) \mathrm{Cl}_{2}\right]$, were synthesized and characterized. Substitution reactions of these complexes with nucleophiles thiourea (TU), L-methionine (L-Met), L-histidine (L-His) and guanosine-5'-monophosphate (5'-GMP) - were carried out in $25 \mathrm{mM}$ Hepes buffer in the presence of $30 \mathrm{mM} \mathrm{NaCl}$. The reactions were monitored using variable-temperature UV-Vis spectrophotometry and were followed under pseudo-first-order conditions with a large excess of nucleophiles. A slightly higher reactivity was found for [Pt(DMEAlm $\left.\left.{ }^{\mathrm{iPr}}\right) \mathrm{Cl}_{2}\right]$, while the reactivity of the nucleophiles decreased in the order TU $>$ L-Met $>$ L-His $>5^{\prime}$-GMP. The negative values reported for the entropy of activation confirmed an associative substitution mode. Spectrophotometric acid-base titrations were performed to determine the $\mathrm{p} K_{\mathrm{a}}$ values of the coordinated water molecules in the diaqua complexes $\left[\mathrm{Pt}\left(\mathrm{DMEAIm}{ }^{\mathrm{iPr}}\right)\left(\mathrm{H}_{2} \mathrm{O}\right)_{2}\right]^{2+}$ and $\left[\mathrm{Pt}\left(\mathrm{DPENIm} \mathrm{m}^{\mathrm{iPr}}\right)\left(\mathrm{H}_{2} \mathrm{O}\right)_{2}\right]^{2+}$. Solubility measurements revealed good solubility of the studied imidazolin-2-imine complexes in water. The crystal structure of $\left[\mathrm{Pt}\left(\mathrm{DMEAIm}{ }^{\mathrm{iPr}}\right) \mathrm{Cl}_{2}\right]$ was determined by $\mathrm{X}$-ray diffraction analysis. The coordination geometries around the platinum atoms are distorted square-planar; the $\left[\mathrm{Pt}\left(\mathrm{DMEAlm} \mathrm{m}^{\mathrm{iPr}}\right) \mathrm{Cl}_{2}\right]$ complex displays $\mathrm{Pt}-\mathrm{N}$ distances of 2.0162(19) and 2.0663(19) A. Attempts to coordinate Au(III) ions to different imidazolin-2-imine ligands did not result in the formation of coordination complexes, but rather in the reduction of the $\mathrm{Au}(\mathrm{III})$ precursor. This was evidenced by the X-ray crystal structure of $\left[\left(\mathrm{DACH}\left(\mathrm{Im}^{\mathrm{i} P r} \mathrm{H}\right)_{2}\right)\left(\mathrm{AuCl}_{2}\right)_{2}\right]$, which formed during the reaction of $\mathrm{KAuCl}_{4}$ with the ligand $\mathrm{DACH}\left(\mathrm{Im}{ }^{\mathrm{iPr}}\right)_{2}$
\end{abstract}

\section{Introduction}

The platinum group metals, $\mathrm{Pt}(\mathrm{II}), \mathrm{Pd}(\mathrm{II})$ and $\mathrm{Au}(\mathrm{III})$, are valence isoelectronic and often form characteristic isostructural squareplanar complexes. ${ }^{1}$ Accordingly, the chemical behavior in solution of structurally analogous Pt(II) and Pd(II) complexes is very similar. ${ }^{2,3}$ Since the late 1970 s, platinum(II) complexes have been well-known for their anti-tumor activity., ${ }^{4,5}$ In the past 50 years a vast variety of structurally different platinum complexes were synthesized and tested, but platinum drug resistance and toxic side effects represent a limiting factor and continuing challenge. ${ }^{4-8}$ The research field of platinum complexes as anti-tumor drugs is still growing and going in the

\footnotetext{
${ }^{a}$ Faculty of Science, University of Kragujevac, R. Domanovića 12, P. O. Box 60, 34000 Kragujevac, Serbia. E-mail: jrosic@kg.ac.rs; Fax: +381 (0)34335040; Tel: $+381(0) 34336223$

${ }^{b}$ Institut für Anorganische und Analytische Chemie, Technische Universität Braunschweig, Hagenring 30, 38106 Braunschweig, Germany

$\dagger$ Electronic supplementary information (ESI) available. CCDC 1431738 and 1431739. For ESI and crystallographic data in CIF or other electronic format see DOI: $10.1039 / \mathrm{c} 5 \mathrm{nj} 03360 \mathrm{~h}$
}

direction of designing novel platinum drugs with distinctly different structural and mechanistic profiles in comparison with cisplatin. In addition, research has been focused on the synthesis and investigation of complexes of different metal ions with the goal to establish compounds with good anti-tumor properties but with no side-effects and lower resistance compared to cisplatin. ${ }^{6-8}$ In recent years, the anti-tumor activity of some $\operatorname{Pd}\left(\right.$ II) complexes has been confirmed, ${ }^{9-11}$ and also square-planar $\mathrm{Au}(\mathrm{III})$ compounds have shown to be excellent candidates for anticancer evaluation. ${ }^{12,13}$

Factors that influence the properties of the complexes such as geometry, steric hindrance, flexibility, electronic effects, and lipophilicity are important to be considered during drug design. In an earlier publication, ${ }^{14}$ we were able to show that the use of hybrid amine-imidazolin-2-imines as strong $\mathrm{N}$-donor ligands ${ }^{15-17}$ afforded Pd(II) complexes with improved properties such as water solubility and lower reactivity toward small biomolecules, which should lead to a more selective distribution of these complexes in the human body. ${ }^{14}$ Therefore, it was of interest to introduce imidazolin-2-imines in the coordination sphere of $\mathrm{Pt}(\mathrm{II})$ and $\mathrm{Au}(\mathrm{III})$ complexes and follow the way how 
this will affect the characteristics of such complexes under physiological conditions as well as their reactivity towards small bio-molecules.

In this paper, we present the synthesis of imidazolin-2-imine $\mathrm{Pt}$ (II) complexes and their interactions with small bio-molecules, in an attempt to define preliminary structure-function relationships within this new class of imidazolin-2-imine complexes. In addition, we report attempts to prepare imidazolin-2-imine $\mathrm{Au}(\mathrm{III})$ complexes.

\section{Results and discussion}

\subsection{Pt(II) imidazolin-2-imine complexes}

2.1.1. Complex synthesis. The Pt(II) complexes $\left[\mathrm{Pt}\left(\mathrm{DMEAIm}^{\mathrm{iPr}}\right) \mathrm{Cl}_{2}\right]$ and $\left[\mathrm{Pt}\left(\mathrm{DPENIm}^{\mathrm{iPr}}\right) \mathrm{Cl}_{2}\right]$ were synthesized by stirring equimolar amounts of $\mathrm{K}_{2} \mathrm{PtCl}_{4}$ and the respective imidazolin-2-imine ligand in THF. The complexes were characterized by ${ }^{1} \mathrm{H}$ and ${ }^{13} \mathrm{C}$ NMR spectroscopy, elemental analysis and ESI-MS mass spectrometry. The mass spectrum of [Pt(DPENIm ${ }^{\mathrm{iPr}} \mathrm{Cl}_{2}$ ] in the $\mathrm{m} / \mathrm{z}$ range of $200-600$ includes main peaks at $m / z=293(2+)$ and 621(1+), which correspond to $\left[\mathrm{Pt}\left(\mathrm{DPENIm}^{\mathrm{iPr}}\right)\right]^{2+}$ and $\left[\mathrm{Pt}\left(\mathrm{DPENIm}{ }^{\mathrm{iPr}}\right) \mathrm{Cl}\right]^{+}$and represent characteristic fragments of the $\left[\mathrm{Pt}\left(\mathrm{DPENIm}{ }^{\mathrm{iPr}}\right) \mathrm{Cl}_{2}\right]$ complex (see Fig. S1, ESI $\dagger$ ). The ${ }^{1} \mathrm{H}$ and ${ }^{13} \mathrm{C}$ NMR spectra indicate hindered rotation along the imine $\mathrm{C}-\mathrm{N}$ bond on the NMR timescale at room temperature. Therefore, the $C_{\mathrm{s}}$-symmetric $\left[\mathrm{Pt}\left(\mathrm{DMEAIm}{ }^{\mathrm{iPr}}\right) \mathrm{Cl}_{2}\right]$ complex exhibits two doublets in the ${ }^{1} \mathrm{H}$ NMR spectrum, which can be assigned to the diastereotopic methyl groups of the isopropyl substituents. In contrast, $C_{1}$-symmetry of the chiral complex [Pt(DPENIm $\left.{ }^{\text {iPr }}\right) \mathrm{Cl}_{2}$ ] affords diastereotopic isopropyl groups, which gives rise to four doublets in the ${ }^{1} \mathrm{H}$ NMR spectrum. Such hindered rotation around the imine $\mathrm{C}-\mathrm{N}$ bond was previously observed for related complexes. ${ }^{15-18}$

Orange single-crystals of $\left[\mathrm{Pt}\left(\mathrm{DMEAIm}^{\mathrm{iPr}}\right) \mathrm{Cl}_{2}\right]$ suitable for $\mathrm{X}$-ray diffraction analysis were obtained from chloroform/ diethyl ether solution, and the molecular structure is shown in Fig. 2. The molecule crystallizes in the monoclinic space group $P 2_{1} / n$, with two co-crystallized molecules of $\mathrm{CHCl}_{3}$ per unit. The diimine ligand is coordinated to the platinum(II) ion in a chelating, bidentate fashion with an N1-Pt-N2 bite angle of 83.04(8) ${ }^{\circ}$. The Pt-N bond lengths are 2.0162(19) $\AA$ and 2.0663(19) § for Pt-N1 and Pt-N2, respectively, indicating stronger coordination of the more basic imine nitrogen to the $\mathrm{Pt}$ atom. The electron-donating capacity of imidazolin-2-imine is also reflected in the different $\mathrm{Pt}-\mathrm{Cl}$ bond lengths, with the Pt-Cl1 (2.3368(6) ̊) trans to the imine nitrogen being notably longer than the Pt-Cl2 (2.3076(5) ̊) trans to the tertiary amine. These structural parameters are comparable to those observed for $\left[\mathrm{Pd}\left(\mathrm{DMEAIm}^{\mathrm{iPr}}\right) \mathrm{Cl}_{2}\right],\left[\mathrm{Pd}\left(\mathrm{DPENIm}{ }^{\mathrm{iPr}}\right) \mathrm{Cl}_{2}\right]$ and $\left[\mathrm{Pd}\left(\mathrm{BL}^{\mathrm{iPr}}\right) \mathrm{Cl}_{2}\right] \cdot{ }^{14,19}$

2.1.2. Solubility of the $\mathrm{Pt}$ (II) imidazolin-2-imine complexes and $\mathrm{pK}_{\mathrm{a}}$ determination of the aqua $\mathrm{Pt}(\mathrm{II})$ complexes. Like the previously reported imidazolin-2-imine Pd(II) complexes, ${ }^{14}$ the $\mathrm{Pt}$ (II) complexes reported herein show good solubility in water, as evidenced by UV-Vis spectrophotometric measurements (Table 1). The solubility of the Pt(II) complexes is greater than<smiles></smiles>

[Pt(DMEAlm $\left.\left.{ }^{i \mathrm{Pr}}\right) \mathrm{Cl}_{2}\right]$<smiles>NC(N)=S</smiles>

Thiourea (TU)

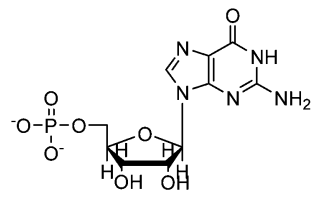

guanosine-

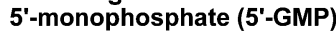

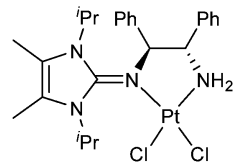

[Pt(DPENIm $\left.\left.{ }^{i P r}\right) \mathrm{Cl}_{2}\right]$<smiles>CSCCC(N)C(=O)[O-]</smiles>

L-Methionine (L-Met)<smiles>N[C@@H](Cc1c[nH]cn1)C(=O)[O-]</smiles>

L-Histidine (L-His)
Fig. 1 Structures of the investigated Pt(II) complexes and nucleophiles, along with their abbreviations.

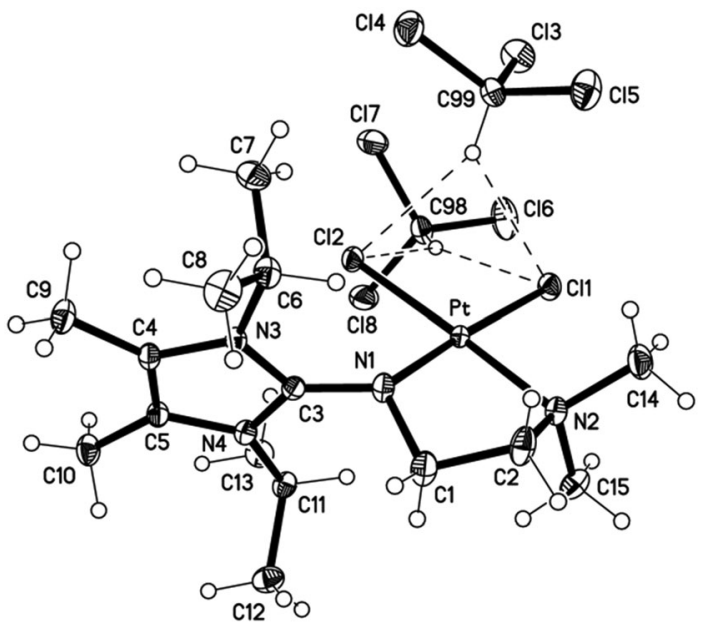

Fig. 2 ORTEP drawing of $\left[\mathrm{Pt}\left(\mathrm{DMEAIm}{ }^{\mathrm{iPr}}\right) \mathrm{Cl}_{2}\right] \cdot 2 \mathrm{CHCl}_{3}$ with thermal displacement parameters drawn at $50 \%$ probability. Hydrogen atoms were omitted for clarity. Selected bond distances $[\AA]$ and angles $\left[^{\circ}\right]$ and contacts: Pt-N1 2.0162(19), Pt-N2 2.0663(19), Pt-Cl1 2.3076(5), Pt-Cl2 2.3368(6), C3-N1 1.365(3), C3-N3 1.351(3), C3-N4 1.350(3); N1-Pt-N2 83.04(8),

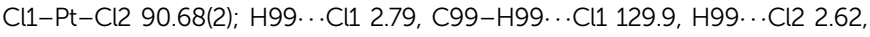
$\mathrm{C} 99-\mathrm{H} 99 \ldots \mathrm{Cl} 2150.3, \mathrm{H} 98 \ldots \mathrm{Cl} 12.64, \mathrm{C} 98-\mathrm{H} 98 \ldots \mathrm{Cl} 1149.1, \mathrm{H} 98 \ldots \mathrm{Cl} 22.79$, $\mathrm{C} 98-\mathrm{H} 98 \ldots \mathrm{Cl} 2135.1$

observed for cisplatin and oxaliplatin (see Table 1). Thus, the introduction of different imidazolin-2-imines affords Pt(II) complexes with satisfactory solubility in water. Good solubility in water is very important in designing metallo-drugs.

The $\mathrm{p} K_{\mathrm{a}}$ values of the complexes in aqueous solution were determined. This was performed via UV-Vis spectrophotometric $\mathrm{pH}$ titration with $\mathrm{NaOH}$ as a base in the $\mathrm{pH}$ range between 2 and 12. Each $\mathrm{p} K_{\mathrm{a}}$ titration was performed twice and the average of both values was taken. Fig. 3 and Fig. S2 (ESI $\dagger$ ) show plots of absorbance 
Table 1 Water solubility of $\mathrm{Pt}(॥)$ and $\mathrm{Pd}(॥)$ imidazolin-2-imine complexes at $298 \mathrm{~K}$

\begin{tabular}{|c|c|}
\hline Complex & Solubility in water at $298 \mathrm{~K}\left(\mathrm{mg} \mathrm{ml}^{-1}\right)$ \\
\hline$\left[\mathrm{Pt}\left(\mathrm{DMEAIm}^{\mathrm{iPr}}\right)\left(\mathrm{H}_{2} \mathrm{O}\right)_{2}\right]^{2+}$ & 9.8 \\
\hline$\left[\mathrm{Pt}\left(\mathrm{DPENIm}^{\mathrm{iPr}}\right)\left(\mathrm{H}_{2} \mathrm{O}\right)_{2}\right]^{2+}$ & 9.6 \\
\hline$\left[\mathrm{Pd}\left(\mathrm{DMEAIm}^{\mathrm{iPr}}\right)\left(\mathrm{H}_{2} \mathrm{O}\right)_{2}\right]^{2+14}$ & 10.2 \\
\hline$\left[\mathrm{Pd}\left(\mathrm{DPENIm}^{\mathrm{iPr}}\right)\left(\mathrm{H}_{2} \mathrm{O}\right)_{2}\right]^{2+14}$ & 10.1 \\
\hline Cisplatin $^{a}$ & 2.5 \\
\hline Oxaliplatin $^{b}$ & 5.0 \\
\hline
\end{tabular}

versus $\mathrm{pH}$ at specific wavelengths, which were used to determine the $\mathrm{p} K_{\mathrm{a}}$ values of the coordinated water molecules. The data were fitted using a nonlinear least-squares procedure, as shown in the insets in Fig. 3 and Fig. S2 (ESI $\dagger$ ). The overall process can be represented by eqn (2) and (3). The titration data for the complexes were fitted to the following eqn (1) for the determination of both $\mathrm{p} K_{\mathrm{a}}$ values, ${ }^{14,20-22}$ and the obtained data are presented in Table 2.

$$
\begin{aligned}
y= & a+(b-a)) /\left(1+2.718 \times\left(\left(x-\mathrm{p} K_{\mathrm{a} 1} / m\right)+(c-b) /(1+2.718\right.\right. \\
& \left.\times\left(\left(x-\mathrm{p} K_{\mathrm{a} 2}\right) / n\right)\right)
\end{aligned}
$$

The parameter $a$ represents the value of the absorbance at the beginning of the titration, $b$ represents the absorbance during the titration and $c$ is the absorbance at the end of the titration. The parameters $m$ and $n$ are used to optimize the titration curve. In this equation $y$ represents the absorbance value and $x$ refers to the $\mathrm{pH}$. The data obtained for the $\mathrm{p} K_{\mathrm{a}}$ values are summarized in Table 2 .

$$
\left[\mathrm{Pt}(\mathrm{L})\left(\mathrm{H}_{2} \mathrm{O}\right)_{2}\right]^{2+}+\mathrm{H}_{2} \mathrm{O} \stackrel{K_{\mathrm{a} 1}}{\rightleftharpoons}\left[\mathrm{Pt}(\mathrm{L})(\mathrm{OH})\left(\mathrm{H}_{2} \mathrm{O}\right)\right]^{+}+\mathrm{H}_{3} \mathrm{O}^{+}
$$

$$
\begin{aligned}
& {\left[\mathrm{Pt}(\mathrm{L})(\mathrm{OH})\left(\mathrm{H}_{2} \mathrm{O}\right)\right]^{+}+\mathrm{H}_{2} \mathrm{O} \stackrel{K_{\mathrm{a} 2}}{\rightleftharpoons}\left[\mathrm{Pt}(\mathrm{L})(\mathrm{OH})_{2}\right]+\mathrm{H}_{3} \mathrm{O}^{+}} \\
& \mathrm{L}=\operatorname{DMEAIm}{ }^{\mathrm{iPr}}, \operatorname{DPEN}\left(\mathrm{Im}^{\mathrm{i} \operatorname{Pr}}\right) \mathrm{NH}_{2}
\end{aligned}
$$

For comparison, the data for $\left[\mathrm{Pt}(\mathrm{en})\left(\mathrm{H}_{2} \mathrm{O}\right)_{2}\right]^{2+}$ and cisplatin have been included in Table 2 as they represent typical $\mathrm{p} K_{\mathrm{a}}$ values for

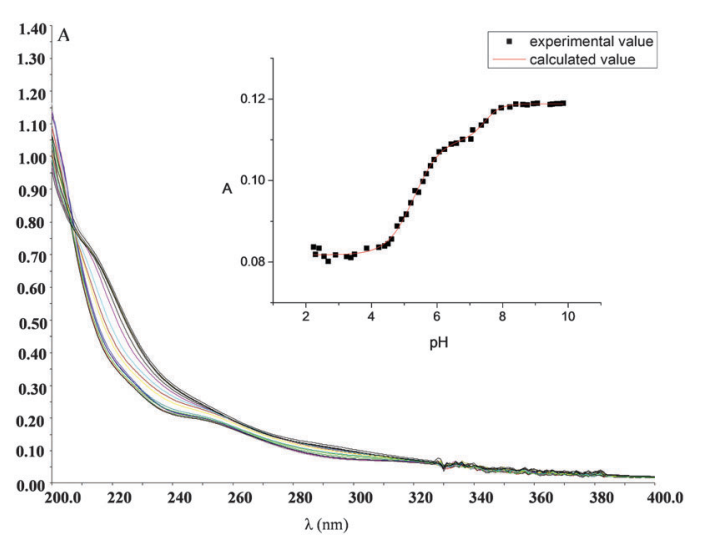

Fig. 3 UV-vis spectra recorded for $0.1 \mathrm{mM}\left[\mathrm{Pt}\left(\mathrm{DMEAlm}{ }^{\mathrm{iPr}}\right)\left(\mathrm{H}_{2} \mathrm{O}\right)_{2}\right]^{2+}$ in the $\mathrm{pH}$ range of 2 to 12 at $25^{\circ} \mathrm{C}$. Inset: The plot of absorbance $v s$. pH at $230 \mathrm{~nm}$.
Table 2 Summary of $p K_{a}$ values obtained for the stepwise deprotonation of the coordinated water ligands in imidazolin-2-imine Pt(॥) complexes

\begin{tabular}{lll}
\hline & $\mathrm{p} K_{\mathrm{a} 1}$ & $\mathrm{p} K_{\mathrm{a} 2}$ \\
\hline$\left[\mathrm{Pt}(\mathrm{en})\left(\mathrm{H}_{2} \mathrm{O}\right)_{2}\right]^{2+22}$ & 5.97 & 7.47 \\
cis $^{2}\left[\mathrm{Pt}\left(\mathrm{NH}_{3}\right)_{2}\left(\mathrm{H}_{2} \mathrm{O}\right)_{2}\right]^{22}$ & 5.37 & 7.21 \\
{$\left[\mathrm{Pt}\left(\mathrm{DMEAIm}{ }^{\mathrm{PPr}}\right)\left(\mathrm{H}_{2} \mathrm{O}\right)_{2}\right]^{2+}$} & $5.44 \pm 0.15$ & $7.73 \pm 0.10$ \\
{$\left[\mathrm{Pt}\left(\mathrm{DPENIm}{ }^{\mathrm{iPr}}\right)\left(\mathrm{H}_{2} \mathrm{O}\right)_{2}\right]^{2+}$} & $6.11 \pm 0.20$ & $9.05 \pm 0.20$ \\
{$\left[\mathrm{Pd}\left(\mathrm{DMEAIm}{ }^{\mathrm{iPr}}\right)\left(\mathrm{H}_{2} \mathrm{O}\right)_{2}\right]^{2+14}$} & $5.75 \pm 0.10$ & $8.28 \pm 0.10$ \\
{$\left[\mathrm{Pd}\left(\mathrm{DPENIm}{ }^{\mathrm{iPr}}\right)\left(\mathrm{H}_{2} \mathrm{O}\right)_{2}\right]^{2+14}$} & $7.17 \pm 0.20$ & $11.21 \pm 0.10$
\end{tabular}

complexes coordinated by $\mathrm{sp}^{3}$-hybridized amines. ${ }^{23}$ It can be seen from Table 2 that both the $\mathrm{Pt}(\mathrm{II})$ as well as the $\mathrm{Pd}(\mathrm{II})$ complexes with imidazolin-2-imine ligands give higher $\mathrm{p} K_{\mathrm{a}}$ values than cisplatin. This can be attributed to the electron-rich nature of the metal centers in these complexes induced by the electron-donating capacity of the imidazolin-2-imines. The studied complexes, $\left[\mathrm{Pt}\left(\mathrm{DMEAIm}^{\mathrm{iPr}}\right)\left(\mathrm{H}_{2} \mathrm{O}\right)_{2}\right]^{2+}$ and $\left[\mathrm{Pt}\left(\mathrm{DPENIm}^{\mathrm{iPr}}\right)\left(\mathrm{H}_{2} \mathrm{O}\right)_{2}\right]^{2+}$, have two different types of donors, viz. an imidazolin-2-imine moiety and an $\mathrm{sp}^{3}$-hybridized primary amine unit. Therefore, it can be assumed that the first aqua ligand to be deprotonated would be that trans to the less electron donating amine donor. By comparing the $\mathrm{p} K_{\mathrm{a}}$ values obtained for the $\mathrm{Pt}(\mathrm{II})$ and $\mathrm{Pd}(\mathrm{II})$ complexes bearing the same imidazolin-2-imines (Table 2), it can be noted that the $\operatorname{Pd}($ II) imidazolin-2-imine complexes show higher $\mathrm{p} K_{\mathrm{a}}$ values than the analogous $\mathrm{Pt}(\mathrm{II})$ complexes.

2.1.3. Kinetic studies. The substitution of two Pt(II) complexes with selected nucleophiles (Fig. 1) was investigated and found to proceed in two successive reaction steps that are both dependent on the nucleophile concentration as presented in Scheme 1 (except for the substitution reaction with L-Met, see text below). The change in absorbance was followed, at suitable wavelengths, as a function of time at $310 \mathrm{~K}$ and $\mathrm{pH} \approx 7.2$. L-Methionine and L-His are essential amino acids, while $5^{\prime}$-GMP is the fragment of nucleic acid. Thiourea is used as a protective and rescue agent to prevent side effects which are caused by $\mathrm{Pt}$ (II) antitumor drugs. ${ }^{24,25}$ Therefore, these compounds are useful to obtain more insights in the way how these Pt(II) complexes interact with bio-molecules, which can help to evaluate the possibility of applying them as anti-tumor agents.

The substitution reactions of square-planar metal complexes can proceed according to two parallel pathways. ${ }^{26}$ One involves the formation of a solvent-coordinated complex, e.g. a diaqua complex, followed by rapid substitution of the coordinated

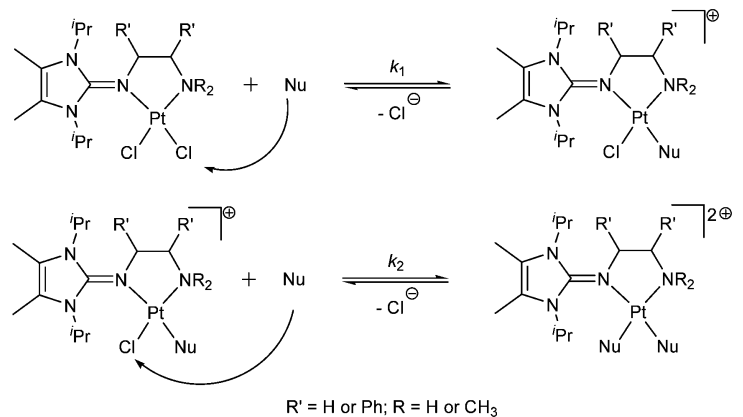

Scheme $1 \mathrm{Nu}=\mathrm{TU}, \mathrm{L}-\mathrm{Met}, \mathrm{L}-\mathrm{His}$ and $5^{\prime}$-GMP. 
solvent by the entering nucleophile (solvolytic pathway), whilst the other involves a direct nucleophilic attack by the entering nucleophile. To suppress the solvolytic pathway, a $30 \mathrm{mM} \mathrm{NaCl}$ solution was added (see Fig. S3, ESI $\dagger$ ). The rate constants for substitution could be determined, under pseudo-first-order conditions from a plot of the linear dependence of $k_{\text {obsd }}$ versus the total nucleophile concentration, according to eqn (4) and (5). The slope of the line represents $k_{1}$ or $k_{2}$, whilst the intercept represents $k_{-1}\left[\mathrm{Cl}^{-}\right]$or $k_{-2}\left[\mathrm{Cl}^{-}\right]$. The results are summarized in Table 3 and Table S10 (ESI $\dagger$ ).

$$
\begin{aligned}
& k_{\mathrm{obsd} 1}=k_{1}[\mathrm{Nu}]+k_{-1}\left[\mathrm{Cl}^{-}\right] \\
& k_{\mathrm{obsd} 2}=k_{2}[\mathrm{Nu}]+k_{-2}\left[\mathrm{Cl}^{-}\right]
\end{aligned}
$$

$\mathrm{Nu}=\mathrm{TU}, \mathrm{L}-\mathrm{Met}, \mathrm{L}-\mathrm{His}$ and $5^{\prime}$-GMP

Fig. 4 shows the dependence of $k_{\text {obsd }}$ on the nucleophile concentration for the $\left[\mathrm{Pt}\left(\mathrm{DMEAIm}{ }^{\mathrm{iPr}}\right) \mathrm{Cl}_{2}\right]$ complex (see also Fig. S4 and S5, ESI $\dagger$ ).

$\left[\mathrm{Pt}\left(\mathrm{DMEAIm}^{\mathrm{iPr}}\right) \mathrm{Cl}_{2}\right]$ reacts faster than $\left[\mathrm{Pt}\left(\mathrm{DPENIm}^{\mathrm{iPr}}\right) \mathrm{Cl}_{2}\right]$ which is in accordance with the order of reactivity observed for analogous Pd(II) complexes. ${ }^{14}$ The second substitution step is slower than the first substitution for both complexes. It can be assumed that the first substitution would take place next to the less sterically hindered side of the ligand viz. next to the amine donor, while, the second substitution would have to take place next to the bulky imidazolin-2-imine donor. In addition, the first substitution would result in a less electrophilic $\mathrm{Pt}$ (II) center, reducing the reaction rate for the second substitution.

The order of the reactivity of the investigated nucleophiles for the first reaction step is: TU $>$ L-Met $>$ L-His $>5^{\prime}$-GMP (Table 3). Thus, the sulfur-donor nucleophiles react faster with $\mathrm{Pt}(\mathrm{II})$ complexes than the nitrogen-donor nucleophiles.

The order of the reactivity for the second substitution step is: TU $>$ L-His $>5^{\prime}$-GMP. Kinetic traces for reactions with L-Met gave fits with a double exponential function. However, when the constants, $k_{\text {obsd } 1}$ and $k_{\text {obsd2 }}$ were plotted against the concentration of the entering L-Met, it was observed that $k_{\text {obsd1 }}$ shows a linear dependence on the nucleophile concentration, while $k_{\mathrm{obsd} 2}$ was found to be independent of the L-Met concentration, suggesting a chelate formation process as presented in Scheme 2 and Fig. 5.

The substitution reactions of the investigated $\mathrm{Pt}(\mathrm{II})$ complexes with L-Met proceed as shown in Scheme 2 with the formation of a six-membered ring via the sulphur and nitrogen atoms of L-Met. Ring-closure and formation of a six-membered ring also occur in the substitution reactions of analogous $\operatorname{Pd}(\mathrm{II})$ complexes with L-Met. ${ }^{14}$ To confirm that the second step is
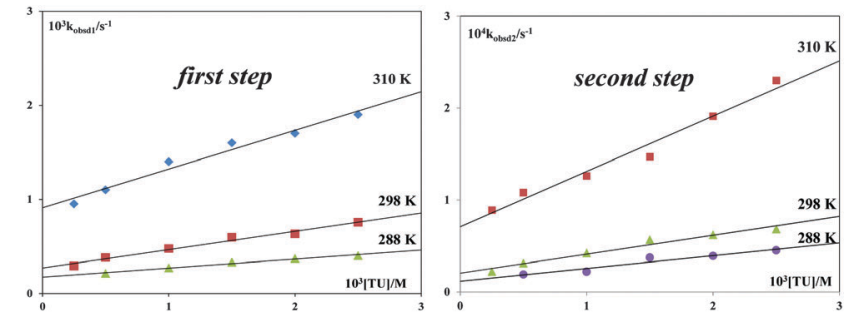

Fig. 4 Pseudo-first-order rate constants plotted as a function of nucleophile concentration for the first step (left graph) and the second step (right graph) of the substitution reactions of the $\left[\mathrm{Pt}\left(\mathrm{DMEAIm}{ }^{\mathrm{iPr}}\right) \mathrm{Cl}_{2}\right]$ complex with $\mathrm{TU}$ at $\mathrm{pH}=7.2$ and $310 \mathrm{~K}$ in $25 \mathrm{mM}$ Hepes buffer and $30 \mathrm{mM} \mathrm{NaCl}$.

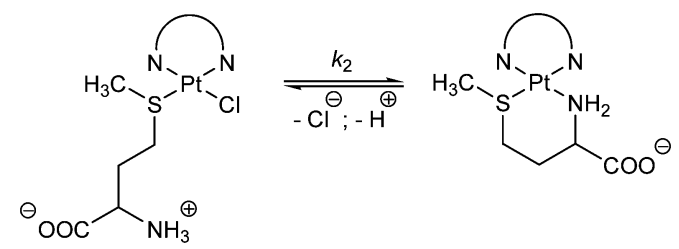

Scheme 2 The second step of the substitution reaction of investigated Pt(॥) complexes with L-Met.

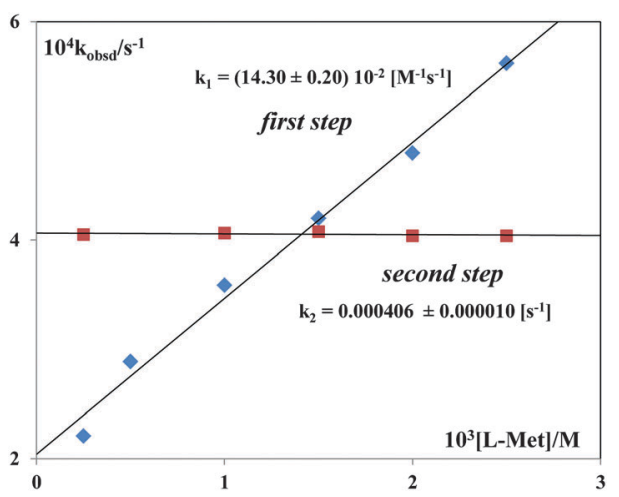

Fig. 5 Plots of $k_{\text {obsd }}$ versus $L-M e t$ concentration for the $\left[\mathrm{Pt}\left(\mathrm{DMEA} / \mathrm{m}^{\mathrm{iPr}}\right) \mathrm{Cl}_{2}\right]$ complex $(\mathrm{pH}=7.2,310 \mathrm{~K}, 25 \mathrm{mM}$ Hepes buffer, $30 \mathrm{mM} \mathrm{NaCl})$.

chelation, the kinetics were studied using the $\mathrm{Pt}(\mathrm{II})$ complexes in excess rather than L-Met. This would mean that a two-step reaction can only occur if ring closure is involved. The obtained kinetic traces for such reactions gave fits to a double exponential function. Similar values for the rate constants were obtained, as were observed in the experiments in which L-Met was added in excess (see Fig. S6, ESI $\dagger$ ).

Table 3 The rate constants for the first and the second reaction step of the substitution reactions of the Pt(II) complexes with TU, L-Met, L-His and

\begin{tabular}{|c|c|c|c|c|}
\hline & \multicolumn{2}{|l|}{$\left[\mathrm{Pt}\left(\mathrm{DMEAIm}^{\mathrm{iPr}}\right) \mathrm{Cl}_{2}\right]$} & \multicolumn{2}{|l|}{$\left[\mathrm{Pt}\left(\mathrm{DPENIm}^{\mathrm{iPr}}\right) \mathrm{Cl}_{2}\right]$} \\
\hline & First step $k_{1}\left[\mathrm{M}^{-1} \mathrm{~s}^{-1}\right]$ & Second step $k_{2}\left[\mathrm{M}^{-1} \mathrm{~s}^{-1}\right]$ & First step $k_{1}\left[\mathrm{M}^{-1} \mathrm{~s}^{-1}\right]$ & Second step $k_{2}\left[\mathrm{M}^{-1} \mathrm{~s}^{-1}\right]$ \\
\hline $\begin{array}{l}\text { TU } \\
\text { L-Met } \\
\text { L-His } \\
5^{\prime} \text {-GMP }\end{array}$ & $\begin{array}{l}(41.10 \pm 0.10) \times 10^{-2} \\
(14.30 \pm 0.20) \times 10^{-2} \\
(3.50 \pm 0.10) \times 10^{-3} \\
(3.30 \pm 0.10) \times 10^{-3}\end{array}$ & 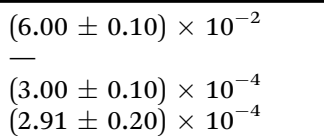 & $\begin{array}{l}(20.90 \pm 0.20) \times 10^{-2} \\
(11.90 \pm 0.10) \times 10^{-2} \\
(2.80 \pm 0.10) \times 10^{-3} \\
(2.59 \pm 0.20) \times 10^{-3}\end{array}$ & $\begin{array}{l}(4.88 \pm 0.20) \times 10^{-2} \\
\overline{(2.16} \pm 0.20) \times 10^{-4} \\
(1.59 \pm 0.10) \times 10^{-4}\end{array}$ \\
\hline
\end{tabular}
$5^{\prime}-\mathrm{GMP}$ at $\mathrm{pH}=7.2$ (25 mM Hepes buffer) in the presence of $30 \mathrm{mM} \mathrm{NaCl}$ at $310 \mathrm{~K}$ 
Table 4 The rate constants for the first reaction step of the substitution reactions of the $\mathrm{Pt}(\mathrm{II})$ complexes with $\mathrm{L}-\mathrm{His}$ and $5^{\prime}$-GMP

\begin{tabular}{|c|c|c|}
\hline & $\mathrm{L}-\mathrm{His} \times 10^{3} k_{1}\left[\mathrm{M}^{-1} \mathrm{~s}^{-1}\right]$ & $5^{\prime}-\mathrm{GMP} \times 10^{3} k_{1}\left[\mathrm{M}^{-1} \mathrm{~s}^{-1}\right]$ \\
\hline$\left[\mathrm{Pt}(\mathrm{en}) \mathrm{Cl}_{2}\right]^{27}$ & $7.90 \pm 0.70$ & $4.40 \pm 0.30$ \\
\hline$\left[\mathrm{Pt}\left(\mathrm{DMEAIm}{ }^{\mathrm{iPr}}\right) \mathrm{Cl}_{2}\right]$ & $3.50 \pm 0.10$ & $3.30 \pm 0.10$ \\
\hline$\left[\mathrm{Pt}\left(\mathrm{DPENIm}^{\mathrm{iPr}}\right) \mathrm{Cl}_{2}\right]$ & $2.80 \pm 0.10$ & $2.59 \pm 0.20$ \\
\hline
\end{tabular}

The activation parameters $\Delta H^{\neq}$and $\Delta S^{\neq}$(Table S1, ESI $\dagger$ ) were calculated using the Eyring equation for the reactions with $\mathrm{TU}$ for the first and second reaction step. The activation parameters support an associative mechanism for each of these reactions which is supported by the significantly negative activation entropies.

The Pd(II) imidazolin-2-imine complexes shows a huge slowdown in reactivity compared with other Pd(II) complexes. Thus, $\left[\mathrm{Pd}\left(\mathrm{DMEAIm}{ }^{\mathrm{iPr}}\right) \mathrm{Cl}_{2}\right]$ and $\left[\mathrm{Pd}\left(\mathrm{DPENIm}^{\mathrm{iPr}}\right) \mathrm{Cl}_{2}\right]$ react 100 times slower than $\left[\mathrm{Pd}(\mathrm{en}) \mathrm{Cl}_{2}\right]$ (en = ethylenediamine $)$ and their reactivity approaches the reactivity of $\mathrm{Pt}(\mathrm{II})$ aqua complexes. ${ }^{14}$ However, the analogous Pt(II) complexes do not show such a pronounced decrease in reactivity as they react only 1.5-2.0 times slower compared to [Pt(en) $\mathrm{Cl}_{2}$ ], Table 4 .

The observed intercepts in Fig. 4 and Fig. S4, S5 (ESI $\dagger$ ) are ascribed to the back reaction with the excess of chloride present in solution. The obtained values of these rate constants are summarized in Table S10 (ESI + ) and they are much smaller in comparison to the values of rate constants for the direct reactions.

\section{2. $\mathrm{Au}(\mathrm{III})$ and imidazolin-2-imines}

Gold(III) complexes can be significantly stabilized, even at neutral $\mathrm{pH}$, by the appropriate choice of the ligand, preserving its interesting biological properties. It was shown that the presence of at least two nitrogen donors directly coordinated with the $\mathrm{Au}$ (III) center leads to a significant decrease in the redox potential of such complexes. ${ }^{12,13,28}$ Keeping this in mind, we attempted to use imidazolin-2-imines as spectator ligands in the synthesis of $\mathrm{Au}(\mathrm{III})$ complexes and to find out whether these ligands can stabilize $\mathrm{Au}(\mathrm{III})$ ions. However, the isolation of stable complexes was not achieved.

The only stable product which we were able to isolate is the product of the reaction between the bis(imidazolin-2-imine) ligand $\mathrm{DACH}\left(\mathrm{Im}^{\mathrm{iPr}}\right)_{2}{ }^{18}$ and $\mathrm{KAuCl}_{4}$ in THF. The product of this reaction was obtained as a yellow solid, ${ }^{1} \mathrm{H}$ and ${ }^{13} \mathrm{C}$ NMR spectroscopy shows characteristic signals of the ligand ${ }^{18}$ (see ESI $\dagger$ ).

Yellow crystals suitable for X-ray diffraction analysis were isolated from a chloroform/diethyl ether solution, and the molecular structure of $\left[\left(\mathrm{DACH}\left(\mathrm{Im}^{\mathrm{iPr}} \mathrm{H}\right)_{2}\right)\right]\left(\mathrm{AuCl}_{2}\right)_{2}$ is shown in Fig. 6. The molecule crystallizes in the monoclinic space group $P 2_{1}$ as a chloroform solvate. The protonated ligand shows $\mathrm{H} \cdots \mathrm{Cl}$ contacts with the $\mathrm{AuCl}_{2}$ counterions of 2.54(7) (H01-Cl1) and 2.46(8) $\AA$ (H02-Cl4). In addition, the protonation of the imine nitrogen atoms causes clear delocalization of the imine double bond, which is indicated by the $\mathrm{C}-\mathrm{N}$ bond distances of the imines of 1.381(6) $\AA(\mathrm{C} 7-\mathrm{N} 1)$ and 1.373(6) $\AA$ (C18-N2).

Apparently, the reaction between $\mathrm{DACH}\left(\mathrm{Im}^{\mathrm{iPr}}\right)_{2}$ and $\mathrm{KAuCl}_{4}$ leads to reduction of $\mathrm{Au}(\mathrm{III})$ to $\mathrm{Au}(\mathrm{I})$, indicating that electron-rich

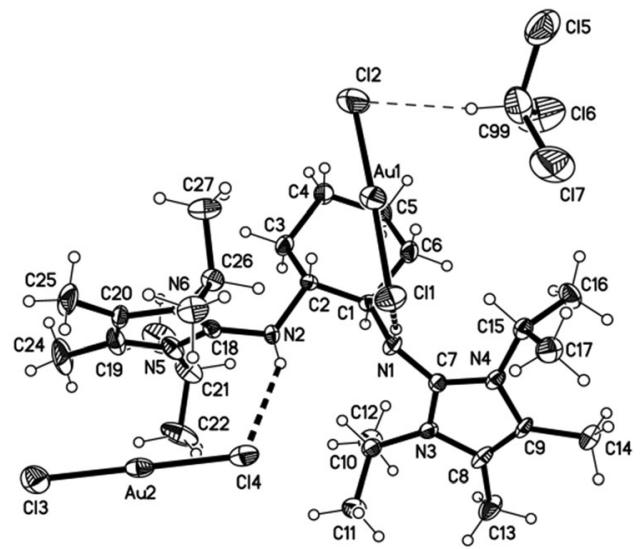

Fig. 6 ORTEP drawing of $\left[\left(\mathrm{DACH}\left(\mathrm{Im}^{\mathrm{iPr}} \mathrm{H}\right)_{2}\right)\right]\left(\mathrm{AuCl}_{2}\right)_{2} \cdot\left(\mathrm{CHCl}_{3}\right)$ with thermal displacement parameters drawn at $50 \%$ probability. Hydrogen atoms were omitted for clarity. Selected bond distances [Å] and angles [ $\left.{ }^{\circ}\right]$ and contacts: C7-N1 1.381(6), C7-N3 1.340(7), C7-N4 1.340(7), C18-N2 1.373(6), C18-N5 1.343(7), C18-N6 1.342(7); N3-C7-N4 109.4(4), N5-C18-N6 108.1(4); $\mathrm{H01} \ldots \mathrm{Cl}$ 2.54(7), $\mathrm{N} 1-\mathrm{H} 01 \ldots \mathrm{Cl} 1$ 165(6), $\mathrm{H02} \ldots \mathrm{Cl} 4$ 2.46(8), $\mathrm{N} 2-\mathrm{H} 02 \ldots \mathrm{Cl} 4$ 146(7), H99...Cl2 2.54, C99-H99...Cl2 170.3.

imidazolin-2-imine ligands are not suited for the complexation of $\mathrm{Au}(\mathrm{III})$. This reactivity can be ascribed to the reducing nature of the imidazolin-2-imine ligands and the oxidizing nature of $\mathrm{Au}(\mathrm{III})$, this is also in agreement with the redox properties reported for guanidine-type ligands. ${ }^{29-32}$

\section{Conclusion}

In this study, two novel platinum(II) complexes with mono(imidazolin-2-imines) were synthesized and characterized; for $\left[\mathrm{Pt}\left(\mathrm{DMEAIm}^{\mathrm{iPr}}\right) \mathrm{Cl}_{2}\right]$, a crystal structure could be determined. Furthermore, the influence of the imidazolin-2-imine ligands on the solubility, acid-base characteristics and reactivity towards bio-molecules of these complexes were studied. We performed spectrophotometric acid-base titrations to determine the $\mathrm{p} K_{\mathrm{a}}$ values for the coordinated water ligands in the respective diaqua complexes. In general, we found two $\mathrm{p} K_{\mathrm{a}}$ values for both studied $\mathrm{Pt}(\mathrm{II})$ complexes. Solubility measurements have shown that Pt(II) complexes with imidazolin-2-imines revealed good solubility in water, which is higher than that of cisplatin and oxaliplatin. The performed kinetic measurements have shown that the complex $\left[\mathrm{Pt}\left(\mathrm{DMEAIm}^{\mathrm{iPr}}\right) \mathrm{Cl}_{2}\right]$ reacts faster than $\left[\mathrm{Pt}\left(\mathrm{DPENIm}^{\mathrm{iPr}}\right) \mathrm{Cl}_{2}\right]$. The reactivity of the studied bio-molecules decreases in the order $\mathrm{TU}>\mathrm{L}$-Met $>\mathrm{L}$-His $>5^{\prime}$-GMP. The investigated nitrogen-donor bio-molecules react with the $\mathrm{Pt}(\mathrm{II})$ complexes in two successive reaction steps that are both dependent on the nucleophile concentration. However, L-methionine reacts by forming a sixmembered ring via its sulphur and nitrogen atoms. The negative values reported for the entropy of activation confirmed an associative substitution mode. The Pd(II) imidazolin-2-imine complexes show a large decrease of reactivity compared with other $\mathrm{Pd}(\mathrm{II})$ complexes, and their reactivity approaches that of $\mathrm{Pt}(\mathrm{II})$ aqua complexes. However, the analogous Pt(II) complexes do not show such a pronounced decrease of reactivity as they 
react 1.5-2.0 times slower compared to $\left[\mathrm{Pt}(\mathrm{en}) \mathrm{Cl}_{2}\right]$. Our attempts to coordinate $\mathrm{Au}(\mathrm{III})$ ions to imidazolin-2-imines were unsuccessful; instead, reduction to $\mathrm{Au}(\mathrm{I})$ was observed.

\section{Experimental}

\subsection{Chemicals and solutions}

Thiourea, L-methionine, L-histidine, guanosine- $5^{\prime}$-monophosphate sodium salt, $N, N$-dimethylethylenediamine, $(1 S, 2 S)-(-)-1,2-$ diphenylethylenediamine, $(1 R, 2 R)-(-)$-1,2-diaminocyclohexane, $\mathrm{NaBF}_{4}, \mathrm{KF}, \mathrm{NaNH}_{2}, \mathrm{KO}^{t} \mathrm{Bu}, \mathrm{K}_{2} \mathrm{PtCl}_{4}$ and $\mathrm{KAuCl}_{4}$ were obtained from Acros Organics or Sigma Aldrich, and were used without further purification. Hepes buffer ( $N$-2-hydroxyethylpiperazine$N^{\prime}$-2-ethanesulfonic acid) was obtained from Sigma Aldrich. All the other chemicals were of the highest purity commercially available and were used without further purification. Ultra-pure water was used in all experiments. Nucleophile stock solutions were prepared shortly before use by dissolving the chemicals.

\subsection{Preparation of the complexes}

All reactions were performed in a glove box, under a dry argon atmosphere (MBraun 200B) or on a high-vacuum line using standard Schlenk techniques, unless noted otherwise. Commercial grade solvents were purified by use of a solvent purification system from MBraun $\mathrm{GmbH}$ and stored over molecular sieves (4 A) under a dry argon atmosphere. The ligands, DMEAIm ${ }^{\text {iPr }}$, DPENIm $^{\text {iPr }}$ and DACH $\left(\operatorname{Im}^{\text {iPr }}\right)_{2}$ were prepared according to the literature procedure. ${ }^{14,18}$

4.2.1. Synthesis and characterization of the $\left[\mathrm{Pt}\left(\mathrm{DMEAIm}^{\mathrm{iPr}}\right) \mathrm{Cl}_{2}\right]$ complex. To a suspension of $100 \mathrm{mg}$ ( $0.24 \mathrm{mmol}$; 1 eq.) of $\mathrm{K}_{2} \mathrm{PtCl}_{4}$ in $5 \mathrm{ml}$ of THF $65 \mathrm{mg}$ ( $0.24 \mathrm{mmol}^{1}$ eq.) of the DMEAIm ${ }^{\text {iPr }}$ ligand in $5 \mathrm{~mL}$ of THF. The reaction mixture was stirred overnight at $50{ }^{\circ} \mathrm{C}$ affording a yellow solution. The complex was precipitated from solution by the addition of $100 \mathrm{~mL}$ of $n$-hexane. The precipitate was dissolved in chloroform to remove $\mathrm{KCl}$, filtered and dried in vacuo. The product was obtained as a yellow-orange solid, the orange crystals were obtained from chloroform/diethyl ether (108 mg, $0.20 \mathrm{mmol}, 84.2 \%)$.

${ }^{1} \mathrm{H}$ NMR (300 MHz; $\left.\mathrm{CDCl}_{3}\right): \delta=5.41$ (sept, $2 \mathrm{H}, J_{\mathrm{HH}} 7.2 \mathrm{~Hz}$, $\left.\mathrm{C} H \mathrm{Me}_{2}\right), 2.93\left(\mathrm{~s}, 6 \mathrm{H}, \mathrm{N}\left(\mathrm{C}_{3}\right)_{2}\right), 2.75\left(\mathrm{t}, 2 \mathrm{H}, J_{\mathrm{HH}} 4.5 \mathrm{~Hz}\right.$, $\mathrm{C}=\mathrm{NCH}_{2} \mathrm{CH}_{2}$ ), $2.45\left(\mathrm{t}, 2 \mathrm{H}, J_{\mathrm{HH}} 4.5 \mathrm{~Hz}, \mathrm{CH}_{2} \mathrm{C}_{2} \mathrm{NMe}_{2}\right), 2.10$ (s, $6 \mathrm{H}, \mathrm{CC}_{3}$ ) 1.55 (d, $\left.6 \mathrm{H}, J_{\mathrm{HH}} 7.0 \mathrm{~Hz}, \mathrm{CH}\left(\mathrm{CH}_{3}\right)_{2}\right), 1.43$ (d, 6H, $\left.J_{\mathrm{HH}} 7.0 \mathrm{~Hz}, \mathrm{CH}\left(\mathrm{CH}_{3}\right)_{2}\right) \mathrm{ppm}$.

${ }^{13} \mathrm{C}$ NMR (100 MHz; $\left.\mathrm{CDCl}_{3}\right): \delta=151.8\left(\mathrm{~N}_{2} \underline{C}=\mathrm{N}\right), 119.2(\underline{\mathrm{CMe}})$, $67.5\left(\mathrm{CH}_{2} \underline{C} \mathrm{H}_{2} \mathrm{NMe}_{2}\right), 51.5\left(\mathrm{C}=\mathrm{NCH}_{2} \mathrm{CH}_{2}\right), 50.8\left(\mathrm{~N}\left(\underline{C} \mathrm{H}_{3}\right)_{2}\right), 48.1$ $\left(\underline{C} \mathrm{HMe}_{2}\right), 22.4\left(\mathrm{CH}\left(\underline{\mathrm{C}} \mathrm{H}_{3}\right)_{2}\right), 21.9\left(\mathrm{CH}\left(\underline{\mathrm{C}} \mathrm{H}_{3}\right)_{2}\right), 10.3\left(\mathrm{C}_{\underline{C}} \mathrm{H}_{3}\right) \mathrm{ppm}$.

Anal. calcd for $\left(\mathrm{C}_{15} \mathrm{H}_{30} \mathrm{Cl}_{2} \mathrm{~N}_{4} \mathrm{Pt}\right) \mathrm{C}: 33.84 ; \mathrm{H}: 5.68 ; \mathrm{N}: 10.52$. Found: C: 33.53; H: 5.49; N: 10.11.

4.2.2. Synthesis and characterization of the $\left[\operatorname{Pt}\left(\operatorname{DPENIm}^{\mathrm{iPr}}\right) \mathrm{Cl}_{2}\right]$ complex. To $50 \mathrm{mg}$ ( $0.12 \mathrm{mmol} ; 1$ eq.) of $\mathrm{K}_{2} \mathrm{PtCl}_{4}$ was added $35.2 \mathrm{mg}$ ( $0.12 \mathrm{mmol}$; 1 eq.) of DPENIm ${ }^{\text {iPr }}$ in $10 \mathrm{~mL}$ of THF. The reaction mixture was stirred for $7 \mathrm{~h}$ at $50{ }^{\circ} \mathrm{C}$, and for two days at room temperature affording a yellow solution. The complex was precipitated from solution by the addition of $100 \mathrm{ml}$ of $n$-hexane. The precipitate was dissolved in chloroform to remove $\mathrm{KCl}$ filtered and dried in vacuo. The product was obtained as a yellow solid (67.6 $\mathrm{mg}, 0.10 \mathrm{mmol}, 85.4 \%)$.

${ }^{1} \mathrm{H}$ NMR (300 MHz; $\left.\mathrm{CDCl}_{3}\right): \delta 7.37-6.85\left(\mathrm{~m}, 10 \mathrm{H}, \mathrm{H}_{\mathrm{Ar}}\right), 5.29$ (sept, 2H, $J_{\mathrm{HH}} 7.0 \mathrm{~Hz}, \mathrm{C} \underline{H} \mathrm{Me}_{2}$ ), 4.96 (d, $1 \mathrm{H}, J_{\mathrm{HH}} 9.0 \mathrm{~Hz}$, $\left.\mathrm{NH}_{2} \mathrm{HC} \underline{H}(\mathrm{Ph}) \mathrm{CH}\right), 4.32$ (d, $\left.1 \mathrm{H}, J_{\mathrm{HH}} 9.0 \mathrm{~Hz}, \mathrm{CNHC} \underline{H}(\mathrm{Ph}) \mathrm{CH}\right)$, 2.14 (s, 6H, CC $\left.\underline{H}_{3}\right), 2.10$ (s, 2H, $\underline{H}_{2}$ ) 1.64 (d, $3 \mathrm{H}, J_{\mathrm{HH}} 7.1 \mathrm{~Hz}$, $\left.\mathrm{CH}\left(\mathrm{CH}_{3}\right)_{2}\right), 1.43\left(\mathrm{~d}, 3 \mathrm{H}, J_{\mathrm{HH}} 7.1 \mathrm{~Hz}, \mathrm{CH}\left(\mathrm{CH}_{3}\right)_{2}\right), 1.03$ (d, 3H, $J_{\mathrm{HH}}$ $\left.7.1 \mathrm{~Hz}, \mathrm{CH}\left(\mathrm{CH}_{3}\right)_{2}\right), 0.84\left(\mathrm{~d}, 3 \mathrm{H}, J_{\mathrm{HH}} 7.1 \mathrm{~Hz}, \mathrm{CH}\left(\mathrm{CH}_{3}\right)_{2}\right)$, ppm.

${ }^{13} \mathrm{C}$ NMR (100 MHz; $\left.\mathrm{CDCl}_{3}\right): \delta 156.8\left(\mathrm{~N}_{2} C=\mathrm{N}\right), 140.1$ (ipso$\underline{C}_{\mathrm{Ar}}\left(\mathrm{CHNH}_{2}\right)$ ), 133.2 (ipso- $\underline{\mathrm{Ar}}_{\mathrm{Ar}}(\mathrm{CHN}), 125.5\left(\underline{C}_{\mathrm{Ar}}\right), 123.1\left(\underline{C}_{\mathrm{Ar}}\right)$, $122.2\left(\underline{C}_{\mathrm{Ar}}\right), 124.7\left(m-\underline{C}_{\mathrm{Ar}}\left(\mathrm{CHNH}_{2}\right)\right), 124.2\left(m-\underline{C}_{\mathrm{Ar}}(\mathrm{CHNH}), 123.9\right.$ $\left(\underline{C}_{\mathrm{Ar}}\right), 119.8(\underline{C M e}) 73.5(\mathrm{CNH} \underline{C H}(\mathrm{Ph}) \mathrm{CH}), 60.4\left(\mathrm{NH}_{2} \mathrm{H} \underline{C} \mathrm{H}(\mathrm{Ph}) \mathrm{CH}\right)$, $49.1\left(\underline{C} \mathrm{HMe}_{2}\right), 48.0\left(\underline{C} \mathrm{HMe}_{2}\right), 22.8\left(\mathrm{CH}\left(\underline{C} \mathrm{H}_{3}\right)_{2}\right), 21.9\left(\mathrm{CH}\left(\underline{C} \mathrm{H}_{3}\right)_{2}\right)$, $21.3\left(\mathrm{CH}\left(\underline{C H}_{3}\right)_{2}\right), 20.1\left(\mathrm{CH}\left(\underline{C} \mathrm{H}_{3}\right)_{2}\right), 11.2\left(\mathrm{C}^{2} \mathrm{H}_{3}\right), 10.8\left(\mathrm{C}^{2} \mathrm{H}_{3}\right) \mathrm{ppm}$.

Anal. calcd for $\left(\mathrm{C}_{25} \mathrm{H}_{34} \mathrm{Cl}_{2} \mathrm{~N}_{4} \mathrm{Pt}\right) \mathrm{C}: 45.73 ; \mathrm{H}: 5.22 ; \mathrm{N}: 8.53$. Found: C: 45.96; H: 5.37; N: 8.71.

4.2.3. Preparation of aqua complexes. The aqua complexes of $\mathrm{Pt}(\mathrm{II})$ complexes were prepared starting from the corresponding chlorido complexes. The conversion was performed by addition of the corresponding amount of $\mathrm{AgClO}_{4}$ to a water solution of the chloride complex and stirring for $5 \mathrm{~h}$ at $50{ }^{\circ} \mathrm{C}$. The white precipitate that formed $(\mathrm{AgCl})$ was filtered off using a Millipore filtration unit, and the solutions were diluted. Great care was taken to ensure that the resulting solution was free of $\mathrm{Ag}^{+}$ions and that the chlorido complexes had been completely converted into the aqua form. Since it is well known that perchlorate ions do not coordinate to $\mathrm{Pd}(\mathrm{II})$ and $\mathrm{Pt}(\mathrm{II})$ in aqueous solution, ${ }^{33} \mathrm{pH}$ titrations were studied in perchlorate medium.

\subsection{Instrumentation and measurements}

NMR spectra were recorded on Bruker DPX 200 and AV 300 devices. Chemicals shifts $(\delta)$ are reported in ppm and referenced to tetramethylsilane. Coupling constants $(J)$ are reported in Hertz (Hz) and splitting patterns are indicated as s (singlet), d (doublet), $\mathrm{t}$ (triplet), sept (septet), bs (broad signal) and $\mathrm{m}$ (multiplet). Elemental analyses $(\mathrm{C}, \mathrm{H}, \mathrm{N})$ were performed by combustion and gas chromatographic analysis using an Elementar Vario MICRO elemental analyzer. High resolution electron spray ionization (ESI) mass spectroscopy was performed on a Finnigan MAT 95 XL Trap device. $\mathrm{pH}$ measurements were carried out using a Mettler Delta 350 digital $\mathrm{pH}$ meter with a resolution of $\pm 0.01 \mathrm{mV}$, equipped with a combination glass electrode. This electrode was calibrated using standard buffer solutions of $\mathrm{pH} 4,7$ and 9 obtained from Sigma. Kinetic measurements of the $\mathrm{Pt}($ II) complex were carried out on a PerkinElmer Lamda 25 and 35 double-beam spectrophotometer in thermostated $1.00 \mathrm{~cm}$ quartz Suprasil cells. The temperature was controlled to $\pm 0.1{ }^{\circ} \mathrm{C}$. All kinetic measurements were performed under pseudo-first-order conditions, i.e., at least a 10-fold excess of the nucleophile was used.

\subsection{Determination of the $\mathrm{p} K_{\mathrm{a}}$ value of the $\mathrm{Pt}(\mathrm{II})$ complexes}

Spectrophotometric $\mathrm{pH}$ titrations of the solutions of the complexes were performed with $\mathrm{NaOH}$ as a base at $298 \mathrm{~K}$. To avoid absorbance corrections due to dilution, a large volume $(300 \mathrm{~mL})$ of the complex solution was used in the titration. The change in $\mathrm{pH}$ from 2 to approximately 3 was achieved by addition of known amounts of 
crushed pellets of $\mathrm{NaOH}$. The consecutive $\mathrm{pH}$ changes were obtained by adding drops of saturated solutions of $\mathrm{NaOH}, 1$ or $0.1 \mathrm{M}$, using a micropipette. To avoid contamination caused by the $\mathrm{pH}$ electrode, it was necessary to take $2 \mathrm{~mL}$ aliquots from the solution into narrow vials for $\mathrm{pH}$ measurements. The aliquots were discarded after the measurements. The total reversibility of the titration could be achieved by subsequent addition of $\mathrm{HClO}_{4}$.

\subsection{Solubility measurements}

The concentrations of saturated solutions of the studied Pt(II) complexes were determined by UV-Vis spectrophotometry. The specific absorptivity of the compounds in water was determined first. This was measured using five dilution series $(5,10,30,40$, and $50 \mathrm{mM})$ of the studied complexes, and then the calibration curve was calculated using the Lambert-Beer law. The slope of the curve gave specific absorptivity.

The required quantity of water solution was added to the $5 \mathrm{ml}$ volumetric flask. The solution was heated up to $298 \mathrm{~K}$. A previously weighed quantity of Pt(II) complexes was added to the volumetric flask until the saturation point occurs. Stirring was continued up to 7 hours at $298 \mathrm{~K}$. The sample was filtered through a $0.20 \mu \mathrm{m}$ membrane filter. A measured quantity of the filtered sample was transferred into another volumetric flask and further dilutions were made. The absorbance was measured using UV-Vis spectrophotometry. The same process was repeated two times.

\subsection{Kinetic measurements}

The kinetics of the substitution of the coordinated chlorides were followed spectrophotometrically by following the change in absorbance at suitable wavelengths as a function of time. The working wavelengths were determined by recording the spectra of the reaction mixture over the wavelength range 220 to $450 \mathrm{~nm}$. All kinetic experiments were performed under pseudo-first-order conditions, for which the concentration of the nucleophile was always in at least a 20-fold excess. The reactions were initiated by mixing $0.5 \mathrm{ml}$ of the $\mathrm{Pt}(\mathrm{II})$ complex solution with $2.5 \mathrm{ml}$ of thermally equilibrated nucleophile solution in the UV-Vis cuvette, and reactions were followed for at least 8 half-lives. The observed pseudo-first-order rate constants, $k_{\text {obsd }}$, represent an average value of two to four independent kinetic runs for each experimental condition. Some of the reactions were studied at three temperatures $(288,298$ and $308 \mathrm{~K})$.

The experimental data are summarized in the ESI, $\dagger$ Tables S2-S9. The values of the constants and other thermodynamic parameters were determined using the computer programs Microsoft Excel 2007 and OriginPro 8.

\subsection{X-ray diffraction studies}

Data were recorded at 100(2) K using an Oxford Diffraction Eos diffractometer with monochromated Mo $\mathrm{K} \alpha$ radiation. The structures were refined anisotropically using the SHELXL-97 program. ${ }^{34}$ Hydrogen atoms were either (i) located and refined isotropically $(\mathrm{NH})$, (ii) included as idealized methyl groups allowed to rotate but not tip or (iii) placed geometrically and allowed to ride on their attached carbon atoms. CCDC 1431738 and 1431739.

\begin{tabular}{|c|c|c|}
\hline & $\begin{array}{l}{\left[\mathrm{Pt}\left(\mathrm{DMEAIm}^{\mathrm{iPr}}\right) \mathrm{Cl}_{2}\right] \cdot} \\
2\left(\mathrm{CHCl}_{3}\right)\end{array}$ & $\begin{array}{l}{\left[\left(\mathrm{DACH}\left(\mathrm{Im}^{\mathrm{iPr}} \mathrm{H}\right)_{2}\right)\right]} \\
\left(\mathrm{AuCl}_{2}\right)_{2} \cdot\left(\mathrm{CHCl}_{3}\right)\end{array}$ \\
\hline Empirical formula & $\mathrm{C}_{17} \mathrm{H}_{32} \mathrm{Cl}_{8} \mathrm{~N}_{4} \mathrm{Pt}$ & $\mathrm{C}_{29} \mathrm{H}_{53} \mathrm{Au}_{2} \mathrm{Cl}_{7} \mathrm{~N}_{6}$ \\
\hline Formula weight & 771.16 & 1127.86 \\
\hline Crystal system & Monoclinic & Monoclinic \\
\hline Space group & $P 2_{1} / n$ & $P 2_{1}$ \\
\hline$a / \AA$ & $11.5923(3)$ & $11.9748(3)$ \\
\hline$b / \AA$ & $16.9429(3)$ & $10.2420(3)$ \\
\hline$c / \AA$ & $14.1236(3)$ & $16.6859(4)$ \\
\hline$\beta 1^{\circ}$ & $90.040(2)$ & $97.307(3)$ \\
\hline Volume $\left[\AA^{3}\right]$ & $2773.98(10)$ & $2029.84(9)$ \\
\hline$Z$ & 4 & 2 \\
\hline Reflections collected & 105084 & 143811 \\
\hline Independent & 8427 & 12219 \\
\hline reflections & {$\left[R_{\mathrm{int}}=0.0558\right]$} & {$\left[R_{\mathrm{int}}=0.0786\right]$} \\
\hline$\rho_{\mathrm{C}} / \mathrm{g} \mathrm{cm}^{-3}$ & 1.846 & 1.845 \\
\hline$\mu / \mathrm{mm}^{-1}$ & 5.843 & 7.708 \\
\hline$R\left(F_{\mathrm{o}}\right),[I>2 \sigma(I)]$ & 0.0231 & 0.0365 \\
\hline$R_{\mathrm{w}}\left(F_{\mathrm{o}}^{2}\right)$ & 0.0419 & 0.0789 \\
\hline Goodness of fit on $\left(F^{2}\right)$ & 1.065 & 1.055 \\
\hline Flack parameter & - & $0.009(5)$ \\
\hline$\Delta \rho / \mathrm{e} \AA^{-3}$ & $1.530 /-1.080$ & $1.630 /-1.486$ \\
\hline
\end{tabular}

\section{Abbreviations}

$\begin{array}{ll}\text { en } & \text { Ethylendiamine } \\ \text { DMEAIm }^{\text {iPr }} & N^{2} \text {-[1,3-Diisopropyl-4,5-dimethylimidazolin-2- } \\ & \text { ylidene]- } N^{1}, N^{1} \text {-dimethyl-1,2-ethanediamine } \\ \text { DPENIm }^{\text {iPr }} & N^{1} \text {-[1,3-Diisopropyl-4,5-dimethylimidazolin-2- } \\ & \text { ylidene]-1,2-diphenyl-(1S,2S)-1,2- } \\ & \text { ethanediamine } \\ & N^{1}, N^{2} \text {-Bis[1,3-diisopropyl-4,5- } \\ \text { DACH }\left(\operatorname{Im}^{\text {iPr }}\right)_{2} & \text { dimethylimidazolin-2-ylidene]-(1R,2R)-1,2- } \\ & \text { cyclohexanediamine } \\ \text { TU } & \text { Thiourea } \\ \text { L-Met } & \text { L-Methionine } \\ \text { L-His } & \text { L-Histidine } \\ 5^{\prime} \text {-GMP } & \text { Guanosine-5'-monophosphate }\end{array}$

\section{Acknowledgements}

The authors gratefully acknowledge financial support from the Ministry of Education, Science and Technological Development Serbia, project No. 172011 and the Deutsche Forschungsgemeinschaft (DFG).

\section{References}

1 Inorganic Chemistry, ed. Z. E. Housecroft and A. G. Sharp, Essex, England, 2005. 
2 Ž. D. Bugarčić, J. Bogojeski and R. van Eldik, Coord. Chem. Rev, 2015, 292, 91.

3 Ž. D. Bugarčić, J. Bogojeski, B. Petrović, S. Hochreuther and R. van Eldik, Dalton Trans., 2012, 41, 12329-12345.

4 (a) B. Rosenberg and L. V. Camp, Nature, 1965, 205, 698; (b) B. Rosenberg, L. V. Camp, J. E. Trosko and V. H. Mansour, Nature, 1969, 222, 385; (c) B. Rosenberg and L. V. Camp, Cancer Res., 1970, 30, 1799; (d) B. Rosenberg, L. V. Camp, E. B. Grimley and A. J. Thomson, J. Biol. Chem., 1967, 242, 1347.

5 Cisplatin, Chemistry and Biochemistry of Leading Antitumor Drugs, ed. B. Lippert, Wiley-VCH, Zürich, 1999.

6 Bioinorganic Medicinal Chemistry, ed. E. Alessio, Wiley-VCH, Weinheim, 2011, ch. 1-4.

7 N. P. E. Barry and P. J. Sadler, Chem. Commun., 2013, 49, 5106.

8 L. Ronconi and P. J. Sadler, Coord. Chem. Rev., 2007, 251, 1633.

9 A. Bechara, C. M. V. Barbosa, E. J. Paredes-Gamero, D. M. Garcia, L. S. Silva, A. L. Matsuo, F. D. Nascimento, E. G. Rodrigues, A. C. F. Caires, S. S. Smaili and C. Bincoletto, Eur. J. Med. Chem., 2014, 79, 24.

10 E. Gao, C. Liu, M. Zhu, H. Lin, Q. Wu and L. Liu, Anticancer Agents Med. Chem., 2009, 9, 356.

11 E. Gao, M. Zhu, H. Yin, L. Liu, Q. Wu and Y. Sun, J. Inorg. Biochem., 2008, 102, 1958.

12 A. Bindoli, M. Pia Rigobello, G. Scutari, C. Gabbiani, A. Casini and L. Messori, Coord. Chem. Rev., 2009, 253, 1692-1707.

13 (a) A. N. Wein, A. T. Stockhausen, K. I. Hardcastle, M. Reza Saadein, S. Peng, D. Wang, D. M. Shin, Z. Chen and J. F. Eichler, J. Inorg. Biochem., 2011, 105, 663; (b) S. J. Berners-Price and A. Filipovska, Metallomics, 2011, 3, 863.

14 J. Bogojeski, J. Volbeda, M. Freytag, M. Tamm and Ž. D. Bugarčić, Dalton Trans., 2015, 44, 17346.

15 X. Wu and M. Tamm, Coord. Chem. Rev., 2014, 260, 116.

16 T. Glöge, D. Petrović, C. G. Hrib, C. Daniliuc, E. Herdtweck, P. G. Jones and M. Tamm, Z. Anorg. Allg. Chem., 2010, 636, 2303.

17 T. K. Panda, S. Randoll, C. G. Hrib, P. G. Jones, T. Bannenberg and M. Tamm, Chem. Commun., 2007, 5007; T. K. Panda, D. Petrovic, T. Bannenberg, C. G. Hrib, P. G. Jones and M. Tamm, Inorg. Chim. Acta, 2008, 361, 2236; T. K. Panda, A. G. Trambitas, T. Bannenberg, C. G. Hrib, S. Randoll, P. G. Jones and M. Tamm, Inorg. Chem., 2009, 48, 5462;
A. G. Trambitas, T. K. Panda, J. Jenter, P. Roesky, C. G. Daniliuc, C. G. Hrib, P. G. Jones and M. Tamm, Inorg. Chem., 2010, 49, 2435; T. K. Panda, C. G. Hrib, P. G. Jones and M. Tamm, J. Organomet. Chem., 2010, 695, 2768; M. Tamm, A. G. Trambitas, C. G. Hrib and P. G. Jones, Terrae Rarae, 2010, 7, 1; A. G. Trambitas, J. Yang, D. Melcher, C. G. Daniliuc, P. G. Jones, Z. Xie and M. Tamm, Organometallics, 2011, 30, 1122; A. G. Trambitas, D. Melcher, L. Hartenstein, P. W. Roesky, C. Daniliuc, P. G. Jones and M. Tamm, Inorg. Chem., 2012, 51, 6753.

18 J. Volbeda, P. G. Jones and M. Tamm, Inorg. Chim. Acta, 2014, 422, 158.

19 J. Bogojeski, R. Jelić, D. Petrović, E. Herdtweck, P. G. Jones, M. Tamm and Ž. D. Bugarčić, Dalton Trans., 2011, 40, 6515.

20 T. Soldatović, S. Jovanović, Ž. D. Bugarčić and R. van Eldik, Dalton Trans., 2012, 41, 876.

21 A. Mambanda, D. Jaganyi, S. Hochreutther and R. van Eldik, Dalton Trans., 2010, 39, 3595.

22 (a) A. Hofmann and R. van Eldik, Dalton Trans., 2003, 2979; (b) H. Erturk, A. Hofmann, R. Puchta and R. van Eldik, Dalton Trans., 2007, 2295; (c) H. Erturk, J. Maigut, R. Puchta and R. van Eldik, Dalton Trans., 2008, 2759; (d) H. Erturk, R. Puchta and R. van Eldik, Eur. J. Inorg. Chem., 2009, 1334.

23 S. J. Barton, K. J. Barnham, A. Habtemariam, R. E. Sue and R. J. Sadler, Inorg. Chim. Acta, 1998, 273, 8.

24 J. Reedijk, Chem. Commun., 1996, 801.

25 J. H. Burchenal, K. Kalaher, K. Dew, L. Lokys and G. Gale, Biochimie, 1978, 60, 961.

26 Inorganic Reaction Mechanism, ed. M. L. Tobe and J. Burgess, Longman, England, 1999, pp. 70, 364.

27 J. Bogojeski, Ž. D. Bugarčić, R. Puchta and R. van Eldik, Eur. J. Inorg. Chem., 2010, 5439.

28 I. Ott, Coord. Chem. Rev., 2009, 253, 167-1681.

29 F. Oton, A. Tarraga and P. Molina, Org. Lett., 2006, 8, 2107.

30 K. G. Caulton, Eur. J. Inorg. Chem., 2012, 435.

31 S. Stang, A. Lebkücher, P. Walter, E. Kaifer and H.-J. Himmel, Eur. J. Inorg. Chem., 2012, 4833.

32 H.-J. Himmel, Topics in Heterocyclic Chemistry, Springer, Berlin, Heidelberg, 2015, pp. 1-39.

33 T. G. Appleton, J. R. Hall, S. F. Ralph and C. S. M. Thompson, Inorg. Chem., 1984, 23, 3521.

34 G. M. Sheldrick, SHELXL-97, Program for the Refinement of Crystal Structure from Diffraction Data, University of Göttingen, Göttingen, Germany, 1997. 